\title{
Cinderella Complex: Theoretical Roots to Psychological Dependency Syndrome in Women
}

\author{
Sneha Saha ${ }^{1}$, Tanishka S. Safri ${ }^{2}$
}

\section{ABSTRACT}

Women's dependency has been a widely debated topic around the world. Back in the 60s-80s, women were limited to their household chores, child rearing practices and were financially dependent on men, and the concept of women dependency on men was phenomenological and acceptable. But when 90s arrived with the drive of women empowerment; women education flourished, they became financially independent and balanced work and personal lives. The concept of women dependency then started confusion and displease among the "new independent women". This theoretical article aims to elaborate on the concept of women dependence and its background. Cinderella Complex is a psychological syndrome that states women are unconsciously driven to be dependent on a dominant figure (preferably male). Relational Theory in relation to Cinderella complex marks distinction in emotional development of men and women. It states that women are primarily driven to connect with others.

Keywords: Women, Dependency, Cinderella Complex, Relational Theory, Psychology, Syndrome.

Traditionally, women have not been expected to confront fear and go beyond it. They have been encouraged to avoid what scares them, taught, from the time they were very young, to do only those things that allow them to feel comfortable and secure. In fact women were not trained for freedom at all, they were trained for dependency. Up to a point, dependency needs are quite normal, for men as well as for women. But women have been encouraged since they were children to be dependent; this kind of dependence upbringing is now seen as psychologically unhealthy by the contemporary society. Any woman who looks within knows that she was never trained to feel comfortable with the idea of taking care of herself, standing up for herself, asserting herself. At best she may have played the game of independence, inwardly envying the boys (and later the men) because they seemed so naturally self-sufficient.

\footnotetext{
${ }^{1}$ Ph.D. Scholar, Faculty of Humanities and Social Sciences, Shree Ramswaroop Memorial University, Lucknow, India

${ }^{2}$ Ph.D. Scholar, Department of Humanities and Social Sciences, Babu Banarasi Das University, Lucknow, India *Responding Author (C) 2016 I S Saha, T Safri; licensee IJIP. This is an Open Access Research distributed under the terms of the Creative Commons Attribution License (http://creativecommons.org/licenses/by/2.0), which permits unrestricted use, distribution, and reproduction in any Medium, provided the original work is properly cited.
} 


\section{Cinderella Complex: Theoretical Roots to Psychological Dependency Syndrome in Women}

Males are educated for independence from the day they're born. Females are taught that they have an option-that someday, in some way, they are going to be rescued from independent living. Women may venture out on their own for a while; they may go away to school, work, and travel; may even make good money, but underneath there is insecurity towards independence. "Only hang on long enough, the childhood story goes, and someday someone will come along to rescue you from the anxiety of authentic living.” (Colette Dowling,1981)

\section{Concept}

Cinderella Complex (also known as the Cinderella syndrome), was first coined by New York therapist Colette Dowling in the early 80s. Basically, it is a complex (or syndrome) that leads women to believe that they are 'damsels in distress' in need of rescuing from a male suitor. Women wait for a "man" to come and take over control of their lives, so that they can live happily and content with standing behind their men. Cinderella Complex is the largely repressed attitudes and fears that keep women from the full use of their minds and creativity forcing them to wait for something or someone external to transform their lives.

"Cinderella Complex" finds its name from the fairy tale princess Cinderella, waiting for her prince charming to rescue her from the evil stepmother and stepsisters. Most modern adaptations of fairy tales, as well as original versions, place gender expectations on women. Perrault's Cinderella provides an example of how the heroine of the story must be "rescued" by a man of princely matter and helped by outwardly forces to achieve recognition and respect. Cinderella does not bear grudges against her oppressors, the stepsisters and stepmother; she is civil and kindhearted. Through this plot, a woman is told that in order to overcome such oppression, one must be patient and virtuous and wait for the day the reward to such endurance arrives in the form of a man. Thus, young women are trained into dependency. Its story revolves around the assumption that women should be "beautiful, polite, graceful, industrious, obedient, and passive". Cinderella operates as a patriarchal instrument, producing and nurturing a psychological dependence in women. The qualities of feminine beauty and virtue are always related with that of conscience. For a woman to be virtuous, she must be beautiful, obedient, patient, sacrificial, and sexually innocent. When a woman lacks any of these feminine qualities, she feels guilty. Dependence therefore becomes a source of freedom from perceived hardship. Instead of becoming independent, women rely on a man as a source of protection, identity, and proof of love.

In Cinderella, the prince validates the womanly qualities through admiration. Her insecurities and hardships vanish at the site of her prince. With the Cinderella complex internalized so deeply in their minds, these females believe that their submissiveness and obedience to the wills of others will help them win a "prince" with whom they would live happily ever after. Therefore, instead of acting out their own potential, they look for a man to lean on and something external to give their lives meaning. They see themselves as princesses waiting for a prince to come to their rescue. 


\section{Cinderella Complex: Theoretical Roots to Psychological Dependency Syndrome in Women}

\section{Symptoms of Cinderella Complex}

Most doctors believe that women who suffer from this complex usually have other deep-seated emotional problems such as low self-esteem and dependency issues. Some women who suffer from the Cinderella complex are unable to accept the men in their lives in a healthy way. Rather than seeing them as normally flawed individuals, they often idolize them. This type of idolization often leads to expectations that are unrealistic and impossible to meet. A woman with these unrealistic expectations may become emotionally wounded by behaviors. For women who suffer from Cinderella type complexes, dependency and low self-esteem seem to be the root causes of the problem. Most psychologists believe that in many cases dependency issues may result from extremely over-protective parenting. In fact, these parents may have escalated normal protective behavior into abusive controlling, in some cases even punishing the child for displaying signs of independence. It is also considered likely that women who suffer this complex were humiliated socially during their formative years, which is often the cause of low self-esteem.

These women do not believe that they have any worth outside that which their Prince has given them. Victims of the Cinderella Complex will always wait to be rescued from life by their prince, no one else will do. They need that male figure to do everything for them; they need his care, no matter what price they wind up paying for it. They will stay in an abusive relationship that fosters this ideal, because they cannot be on their own, and fear any change that will take them away from their prince. According to Dowling, psychological effects of Cinderella Complex are lack of self esteem, lack of confidence, anxiety and inability to function in the work place.

\section{Relational Theory: A Theoretical Explanation to Dependency}

Over the past three decades, there has been a recognition and acknowledgement of the differences between women and men. One difference is the way in which men and women develop psychologically. Jean Baker Miller posed the question of how women develop in her 1976 book, Toward a New Psychology of Women. Until then, traditional theories of psychology described development as a climb from childlike dependence to mature independence. A person's goal, according to these theories, was to become a self-sufficient, clearly differentiated, autonomous self. A person would spend his or her life separating and individuating until he or she reached maturity, at which point the person was equipped for intimacy.

Miller challenged the assumption that separation was the route to maturity. She suggested that those theories might be describing men's experience, while a woman's path to maturity was different. A woman's primary motivation, said Miller, is to build a sense of connection with others. Women develop a sense of self and self-worth when their actions arise out of, and lead back into, connections with others. Connection, not separation, is the guiding principle of growth for women.

Previously, theoreticians had treated women's emphasis on connection as a sign of deficiency. Working at the same time as Miller, Carol Gilligan, a developmental psychologist, was gathering 


\section{Cinderella Complex: Theoretical Roots to Psychological Dependency Syndrome in Women}

empirical data that reflected fundamental gender differences in the psychological and moral development of women and men (Gilligan, 1982). In her book, In a Different Voice: Psychological Theory and Women's Development, Carol Gilligan observed, “The disparity between women's experience and the representation of human development, noted throughout the psychological literature, has generally been seen to signify a problem in women's development. Instead, the failure The Stone Center at Wellesley College was created for the purpose of thinking through the qualities of relationships that foster healthy growth in women (Jordan, 1984, 1985; Jordan \& Surrey, 1986; Kaplan, 1984; Surrey, 1985). The basic assumption of the Stone Center model is that "connection" is a basic human need, and that this need is especially strong in women (Jordan, Kaplan, \& Miller, 1991). All people need both connection with others and differentiation from others, but females are more attuned to connection while males are more attuned to differentiation. Bylington (1997) explained this connection as follows: Theoretically, girls perceive themselves to be more similar than different to their earliest maternal caretakers, so they do not have to differentiate from their mothers in order to continue to develop their identities. This is in contrast to boys, who must develop an identity that is different from the mother's in order to continue their development. Thus, women's psychological growth and development occur through adding to rather than separating from relationships. Consequently, defining themselves as similar to others through relationships is fundamental to women's identities.

A "connection" in the Stone Center relational model is "an interaction that engenders a sense of being in tune with self and others, of being understood and valued” (Bylington, 1997, p. 35). True connections are mutual, empathic, creative, energy-releasing, and empowering for all participants (Miller, 1986). Such connections are so crucial for women that women's psychological problems can be traced to disconnections or violations within relationshipswhether in families, with personal acquaintances, or in society at large.

Growth fostering relationships empower all people involved in them. They are defined by:

1. A sense of zest or well being that comes from connecting with another person;

2. The ability and motivation to take action in the relationship as well as in other situations;

3. Increased knowledge of oneself and the other person;

4. An increased sense of worth;

5. A desire for more connections beyond the particular one.

\section{A Social Experiment}

To summarize, both of these well established concepts presume that women dependency is in built, culturally strengthened and emotionally developed in women. This drive to depend on someone, limits the self actualization capacity in women. Women try to mould themselves as a desirable partner for their men. Debate arises when these old theories find their way to this $21^{\text {st }}$ century women. As a part of writing this paper, a small social experiment was conducted; a room full of 100-140 Indian women of various age groups was gathered together. Some of these women were working; some studying and some were housewives. Some of these women were 


\section{Cinderella Complex: Theoretical Roots to Psychological Dependency Syndrome in Women}

married and some were single ready to be married. These women were asked about the story of Cinderella. It was observed that each one of them remembered "Cinderella being rescued by Prince Charming” more than Evil Step Family and Fairy God Mother. Then these women were given details about the concept of Cinderella complex in an outline. It was interesting to observe that almost every working and studying women were in denial. They argued that they work and study at their own will and decisions. The housewives of the groups were non-verbally responsive in affirmation to the concept of Cinderella complex. When the working women were explained in detail about Cinderella complex it was found that they started relating to the syndrome. Working women realized their financials are closely guarded and guided by their men, which they are happy and relaxed about. Single women realized they have been reared to make a good wife one day. Housewives realized they have lost themselves to the concept of Cinderella complex.

\section{CONCLUSION}

This kind of realization in $21^{\text {st }}$ century women shows the lessened yet strong relevance of dependency in women psyche. It is important to conduct researches on women dependency, as the review found on this dimension is more than 15years old. As a part of targeted research, this concept should be thoroughly researched on Indian population, researches on this syndrome has not been conducted in India as of yet.

\section{REFERENCES}

Bylington, D. (1997). Applying relational theory to addiction treatment. Gender and addictions: Men and women in treatment. S.L.A. Straussner and E. Zelvin (Eds.) Northvale, NJ: Aronson, pp. 33-45.

Dowling Colette (1981).The Cinderella Complex, Women’s hidden fear of independence, pp.36, Pocket Books, New York

Gilligan, C., Lyons, N. P., and Hanmer, T. J. (Eds.). (1990). Making connections. Cambridge, MA: Harvard University Press.

Jean Baker Miller, M.D. The Five Good Things

Jordan, J.V., Kaplan, A.G., Miller, J.B., et al. (1991). Women's growth in connection: Writings from the Stone Center. New York: Guilford Press.

Miller, J. B. (1986). What do we mean by relationships? Work in Progress No. 22. Wellesley, MA: Stone Center, Working Paper Series.

How to cite this article: S Saha, T Safri (2016), Cinderella Complex: Theoretical Roots to Psychological Dependency Syndrome in Women, International Journal of Indian Psychology, Volume 3, Issue 3, No. 8, DIP: 18.01.148/20160303, ISBN: 978-1-365-12176-0 